\title{
ENERGY SAVING ON CAMPUS: A COMPARISON OF STUDENTS' ATTITUDES AND REPORTED BEHAVIOURS IN THE UK AND PORTUGAL
}

Debby Cotton

Plymouth University, Pedagogic Research Institute and Observatory, 3 Endsleigh Place, Devon PL4 8AA, Plymouth, United Kingdom. Email: D.Cotton@plymouth.ac.uk

Chris Shiel

Bournemouth University, Faculty of Science \& Technology, Poole Dorset, BH12 5BB, Bournemouth, United Kingdom. Email: cshiel@bournemouth.ac.uk

Arminda do Paço ${ }^{1}$

University of Beira Interior, Department of Business and Economics, NECE, Estrada do Sineiro s/n, 6200-209 Covilhã, Portugal. Email: apaco@ubi.pt

Accepted for publication in Journal of Cleaner Production, 15/03/16

\footnotetext{
${ }^{1}$ Corresponding author
} 
This is an Accepted Manuscript of an article published by Elsevier in The Journal of Cleaner Production, available at: doi:10.1016/j.jclepro.2016.03.136

\begin{abstract}
Energy saving on campus is an increasingly important part of universities' responses to climate change, but can only be fully realised through a partnership between institutions and students. This study explores similarities and differences between students' energy-related attitudes and reported behaviours, as well as their perceptions of their institution's energy saving efforts using data from two universities in the United Kingdom (UK) and one in Portugal. The results indicate that there are differences between the students' responses at the selected universities which appear to reflect the national context and diverse institutional priorities. Key differences include the variation between students' perceptions of individual agency and their university's environmental practices (stronger in the UK) and students' sense of collective agency and trust in the government and business (stronger in Portugal). The study is the first to attempt a comparison between students from institutions in different countries in relation to energy saving. It provides a foundation to extend the comparison to other institutions and other countries, and to expand the research to encompass actual energy use, in relation to perceived energy use.
\end{abstract}

\title{
Key words
}

Energy efficiency; Climate change; Higher education; Europe; Environmental attitudes; Campus 


\section{Energy Saving on campus: A comparison of students' attitudes and reported behaviours in the UK and Portugal}

\section{Introduction}

Energy efficiency has an increasingly important role to play in responses to climate change at both an individual and organisational level (IPCC, 2014). Personal consumption patterns (consumer behaviour, household energy use, dietary changes etc.) are identified as crucial elements in the move towards lower carbon emissions, thus efforts to promote energy-saving behaviour change form an important part of the policy agenda (Brounen et al., 2012; Geller et al., 2006). Unfortunately, even when people are motivated to change their behaviour with regard to energy saving, many lack sufficient understanding to make appropriate decisions (Gardner and Stern, 2008; Lorenzoni et al., 2007), or fail to change their habitual responses to similar situations even in the light of altered intentions (Kastner and Matthies, 2014).

Most energy saving activities are of the low-effort, low impact variety, and even more numerate individuals are only slightly more likely to gauge accurately the amount of energy saved by different actions (Attari et al., 2010). This suggests that enhancing energy literacy throughout all levels of education has an important role to play in encouraging energy saving behaviour (Liu et al., 2015). As DeWaters and Power (2013) argue: "a successful shift into a stable future will rely not only on qualified technical, scientific, and professional expertise, but also on the ability of the average citizen to make appropriate energy related choices that range from mode of transportation to consumer purchases and voting habits." (p. 38).

The role of education in ensuring a more sustainable future is not in doubt: the recent United Nations 'Decade of Education for Sustainable Development' (DESD) (UN 2005-2014) has provided a focus for the development of a range of educational initiatives with the overarching goal of integrating the values of sustainable development into all aspects of learning and, ultimately, encouraging behaviour change (UNESCO, 2015). Universities have a key role to play, as has been highlighted consistently in policy documents. However, despite a global movement that has repeatedly emphasised the role of universities through research, campus greening and education for sustainability (Sterling et al., 2013; Wals, 2014), there is less evidence of the impact of such endeavours on students' practical actions such as personal energy saving behaviours.

This may seem surprising as across Higher Education (HE), 'campus greening' initiatives (particularly energy-saving measures by university estates teams) have progressed rapidly (Leal Filho, 2010). Embedding education for sustainability (EfS) within the curriculum has been slower and more problematic and yet there is strong potential for universities to influence students' energy saving 
This is an Accepted Manuscript of an article published by Elsevier in The Journal of Cleaner Production, available at: doi:10.1016/i.jclepro.2016.03.136

behaviour. In theory, sustainability across the campus and the curriculum are inter-related (students learn not just from the formal curriculum, but also from the informal and hidden curricula, through social experiences and the campus environment). In practice, however, sustainability work related to energy saving on campus is rarely integrated with teaching and learning, and the wider student experience (Winter and Cotton, 2012). Energy saving will continue to be as critical for universities as for businesses and households across the European Union, particularly in the UK where sector level carbon reduction targets exist for HE. Thus, the aim of this study is to begin to explore the perspectives of students in relation to energy saving and to understand whether responses vary depending on institutional and national contexts.

The objective of this research was to compare students' perceptions of their campus environmental practices, and to explore their attitudes and reported behaviours regarding energy saving, using data collected from three institutions: one from Portugal (PT) and two from the United Kingdom (UK). Piloting of the survey instrument in the UK has revealed a number of interesting insights into student energy literacy (Cotton et al., 2015a) which can be summarised as follows:

- Reported knowledge of energy was correlated with actual knowledge on a series of factual questions, and this differed by gender;

- The students surveyed had broadly positive environmental attitudes (measured using the NEP scale) and were concerned about energy issues;

- Respondents were very unclear about which activities were most effective in terms of energy saving, limiting the efficacy of their indicated behavioural choices;

- Nearly $50 \%$ of respondents cited formal education as their major source of information about energy saving.

In order to explore whether these findings were specific to the pilot study students, the survey is also being conducted in other institutions in the UK and internationally. The rationale for including an international dimension was to investigate any variation in responses in a different cultural and policy context.

In Portugal, discussion around the role of universities in relation to sustainable development has been almost non-existent, and the few events organised have been limited to an environmental perspective (Shiel and Paço, 2012). In contrast, within the UK, universities across the sector have engaged in 'campus greening', sought to develop education for sustainability, and initiated a range of projects to enhance awareness of and action for sustainable development. The increase in engagement in the UK has in part been driven by the Higher Education Funding Council for England policies (HEFCE, 2005; 2009), sector targets for carbon reduction (HEFCE, 2010), and also by the People and Planet Green League, launched in 2007. The latter, with high profile rankings published in the Times Higher Education initially and later the newspaper The Guardian, has been a critical driver in raising the profile of sustainable development with senior staff (Shiel and Williams, 2015). However, in both contexts there is 
This is an Accepted Manuscript of an article published by Elsevier in The Journal of Cleaner Production, available at: doi:10.1016/j.jclepro.2016.03.136

currently little research literature concerning the extent to which campus greening and EfS impact on students' behaviours in relation to energy consumption.

\section{Literature review}

\subsection{Greening the campus and curriculum}

Energy saving issues are assuming increasing relevance internationally: Aside from having a direct impact on monthly costs for individuals and organisations, energy saving is considered to be the fastest, most effective and profitable way of reducing carbon dioxide emissions and thus mitigating the impacts of climate change. In this context, public institutions are being asked (and increasingly incentivised) to participate in energy conservation. For universities, the responsibility goes beyond direct energy saving in buildings and extends to the potential influence that Education for Sustainability (EfS) in formal and informal learning environments might have on students' attitudes and conservation behaviours. Whilst it is clear that there are substantial differences in universities' responses to the sustainability imperative there are, as yet, very few studies that compare attitudes towards the environment (and subsequent behaviours), of students from different European countries.

Approaches to campus greening in HE have varied over time. In the late 1990s, solid waste and energy management were seen as two of the most popular areas of environmental management (Creighton, 1999), with the suggestion that the effective management of both demonstrates for students the practical application of environmental conservation principles. Since then, campus greening has extended to embrace a broader range of concerns; however, energy saving continues to be a significant component. Many institutions now showcase innovative approaches to sustainability on campus through energy projects such as renewable energy installations, wind turbines, geothermal projects, biomass production, conservation retrofits (Thomashow, 2014). Universities around the world have sought to adapt and innovate in order to save energy; they have been less successful at integrating the sustainable management of their estates with the curriculum (Leal Filho et al., 2015).

There is an increasing interest in the relationship between campus sustainability and education (Jones et al., 2010), particularly as evidence grows which indicates that what happens outside the classroom either reinforces, or challenges, what students learn in the formal curriculum (Cotton et al., 2013). If universities conduct their estates management in an unsustainable manner, for instance through poor energy management in buildings, this may negate the effectiveness of efforts to teach about sustainability in general, and energy saving in particular. On the other hand, a university may be engaging with exceptional energy-saving measures on campus but efforts go unseen by students, or 'mixed messages' may undermine efficacy (Cotton et al., 2013). This tension between campus and curriculum has been used to advocate for a more holistic approach as part of a 'sustainable university' (Sterling et al., 2013), where 'integrative approaches' (Leal Filho et al., 2015) ensure that sustainability permeates all aspects of university business and synergies are created. 
This is an Accepted Manuscript of an article published by Elsevier in The Journal of Cleaner Production, available at: doi:10.1016/i.jclepro.2016.03.136

\subsection{Knowledge, attitudes and behaviour - a thorny issue}

The relationship between environmental knowledge, attitudes and behaviour is complex and there is considerable disagreement about whether they are related, and about the direction of any causal links (Hines et al., 1987). A number of advanced models have been developed to test the mediating and moderating influence of particular variables on the attitude-behaviour link, and to explore the specific conditions whereby an attitude may impact upon behaviour (e.g. Bamberg and Möser, 2007; Barr 2007). However, results have been mixed: Cleveland et al. (2005) state that general environmental attitudes tend to be poor predictors of behaviour; in contrast, Balderjahn (1988) concluded that individuals who had a positive attitude towards the environment were more likely to purchase and consume green products. Laroche et al. (2001) lend further support for this argument suggesting that attitudes, as opposed to knowledge, are the most significant predictors of consumers' willingness to pay more for environmentally friendly products. Barr (2007) in a UK study, explores environmental values, situational characteristics, and psychological factors in relation to waste management behaviours. His results show that recycling is characterised as a highly normative behaviour (which can be influenced by increasing awareness); but reduction and re-use are predicted by underlying values which are more difficult to influence. He warns however that behaviour must be seen in context - thus generalisations in this area are problematic.

According to Tikka et al. (2000), an individual's attitudes, the extent of nature-related activities, and knowledge about the environment are correlated with one another but the educational backgrounds of individuals also appear to affect responses. In addition, other underlying factors - such as gender function as mediating variables. However, empirical findings are somewhat contradictory with respect to gender: Several studies indicate that females are more likely to demonstrate positive environmental attitudes than males (Lukman et al., 2013; Zelezny et al., 2000); and some also indicate that they have more pro-environmental behaviours (Zelezny et al., 2000). However O'Shaughnessy and Kennedy (2010) record more environmental concern amongst females, but lower levels of engagement in environmental practices. In samples across a broad age range, age may also be an intervening variable: Hume (2010) suggests that although young adults are considered socially, economically and environmentally conscious, some contradictions exist between their knowledge and behaviour regarding sustainability efforts. It is also suggested that research needs to consider the influence of context (Barr et al., 2011a) and the different spaces in which consumption takes place (Barr et al., 2011b).

In terms of the link between knowledge and behaviour, studies of university students suggest that high levels of knowledge about sustainability do not necessarily lead to more sustainable behavioural choices, although a lack of knowledge may make it more difficult for them to select the most appropriate behaviour. In both New Zealand (Shephard et al., 2009) and the UK (Cotton et al., 2015a) research has found significant confusion among students about appropriate pro-environmental behaviours - which limits the efficacy of their subsequent activities. However, although improving information about energy use is important, it may not be sufficient to influence behaviour, since other factors such as convenience and cost are likely to intervene. A national survey of UK students focusing on energy-saving behaviour, 
This is an Accepted Manuscript of an article published by Elsevier in The Journal of Cleaner Production, available at: doi:10.1016/i.jclepro.2016.03.136

found that $72 \%$ of respondents claimed to take energy-saving actions but only $25 \%$ reduced their personal air travel (Drayson et al., 2013).

Moreover, Orr (1994:5) argued that there is no correlation between educational level and environmental concern, and claimed that education institutions may in fact be part of the problem of environmental destruction: "The conventional wisdom holds that all education is good, and the more of it one has, the better ... The truth is that without significant precautions, education can equip people merely to be more effective vandals of the earth". While Orr's words offer a pertinent caution, there is evidence emerging, at least in the UK, of a correlation between young people's participation in HE and subsequent commitment to environmental sustainability when other factors are held constant (Cotton and Alcock, 2012). Clearly, this is an area where more research is still needed.

\subsection{Comparative research on environmental sustainability}

With regard to comparisons between countries, assumptions about similar levels of environmental consciousness do not equate to similar levels of pro-environmental behaviour. Public opinion in relation to environmental concern is generally positive across European countries; however there are substantial differences in the intensity of concern (European Commission, 2008). For example, while Europeans appear to attach great importance to environmental protection (96\%) with almost everybody stating that the issue is very or fairly important to them (for instance, Portugal - 97\%, UK - 94\%), the "Attitudes of European citizens towards the environment", a "Special Eurobarometer Report" (European Commission, 2008) presents evidence that consumers differ in terms of their environmental consciousness and behaviours. The report shows that the UK and Germany are the only countries where respondents believe that consumers have a responsibility to make a difference to environmental protection. When asked if they were ready to buy environmentally friendly products even if they cost a little more, the Portuguese appear at the lower end of the rankings, with the smallest percentage of people who would buy environmentally friendly products (59\%); UK citizens present above the European mean (64\%).

Previous research has analysed the nature and frequency of conservation activities (including energysaving behaviour), and the implications for public policy (Pickett et al, 1995) where conservation activity comprises a broad range of items: dispositional activity, recycling of non-durable goods and their packaging, preservation of resources and attitudes towards packaging. Pickett et al. (1995) found that the individuals less involved in such conservation activities seem also to be less affected by pollution problems and less concerned with social problems. In a study which focused specifically on HE students from four countries (Germany, UK, Spain and Portugal), differences between contexts were noted: the English sample had the highest means for almost all conservation activities, apart from saving water whilst washing dishes (Paço et al., 2013). In general, mean values for the English sample were particularly high for the questions related to waste separation/recycling, energy conservation and water saving when compared to the Portuguese students who presented the lowest mean scores for almost all items, being the group that engages least with recycling and saving resources, and caring least about packaging. It might therefore be expected that there will be similar differences with regard to energy saving. Other comparative studies of attitudes and behaviours in relation to "green consumerism" 
This is an Accepted Manuscript of an article published by Elsevier in The Journal of Cleaner Production, available at: doi:10.1016/j.jclepro.2016.03.136

suggest variations across cultures (Autio et al., 2009; Batley et al. 2001) and emphasise the importance of comparison between countries "with different participatory systems" (Oliver and Lee, 2010).

\subsection{Research aims}

On the basis of the literature, this paper aims to extend (albeit in a small way) research comparing attitudes and behaviours across two particular cultures, and three different institutional settings, with specific regard to energy. The research is exploratory and part of a larger study that will determine the extent to which campus greening and EfS impact on students' reported behaviours particularly in relation to energy consumption. Further work may include comparisons with other countries and institutions at different stages of implementing Efs. For the current study, two UK institutions participated (one with a history of high level of engagement with EfS; the other with more moderate engagement) and one Portuguese institution where there has been very limited engagement with EfS.

On the basis of previous research findings, the following null hypotheses were formulated:

$\mathrm{H}_{1}$ : There are no significant differences between students of the universities in the United Kingdom and Portugal regarding attitudes towards energy conservation.

$\mathrm{H}_{2}$ : There are no significant differences between students of the universities in the United Kingdom and Portugal regarding reported energy saving behaviours.

$\mathrm{H}_{3}$ : There are no significant differences between students of the universities in the United Kingdom and Portugal regarding their perception of their own energy usage.

H3.1: There are no significant differences between male and female students regarding their perception of their own energy usage.

\section{Context for the study}

A brief description of the three universities that participated in this study is presented below to set the context for the subsequent analysis and discussion.

At the University of Beira Interior (UBI), one of the most interesting physical features of the university is that its estate comprises old buildings with historical, cultural and architectural value, which have been repaired and conserved. At the same time that these historical landmarks have been re-constructed, they have been revitalized into teaching and investigation spaces. In this way the institution has been promoting both sustainable construction and building conservation in a way that exemplifies preserving the past for the needs of future generations. However the University has no formal policy or strategy in place for sustainable development. It has made some efforts related to energy, water saving and recycling but not as part of an overarching strategic approach. In relation to the curriculum, there is no drive to incorporate sustainable development into formal education. There are a few post graduate 
This is an Accepted Manuscript of an article published by Elsevier in The Journal of Cleaner Production, available at: doi:10.1016/j.jclepro.2016.03.136

courses that partially address sustainability but, beyond that, EfS is not being considered across disciplines.

Plymouth University (PU) is the sixth largest in England, and is currently placed first in the UK People and Planet Green League (People \& Planet Organisation, 2015). It received funding from the Higher Education Funding Council for England (HEFCE) in 2005 under the CETL (Centres for Excellence in Teaching and Learning) scheme to set up the Centre for Sustainable Futures (HEFCE, 2005), and has won several 'Green Gown Awards'. It has also been a recipient of Revolving Green Fund monies from HEFCE to embed energy saving measures (HEFCE, 2010), and was of the first two HEls to gain Silver Accreditation in the LIFE (Learning in Future Environments) programme (EAUC, 2015). Thus, it provides a context in which curriculum and campus greening issues have been taken seriously.

Bournemouth University (BU) is a medium-sized UK university. The vision for the university includes the aim of "inspiring our students, graduates and staff to enrich the world" and the bold statement: "we will ensure our environmental credentials are held in high esteem" (BU, 2018). BU has consistently appeared in the top ten of the People and Planet Green League table. Initiatives at BU have been rewarded by external recognition both locally and nationally, for example: an Earth Charter Award Engagement in Sustainability 2013; EcoCampus Gold Award 2011; various Green Gown Awards and twice short-listed for Times Higher Education Awards - Outstanding Contribution to Sustainable development (2007 and 2011). Staff are encouraged to address EfS across the curriculum.

\section{Methods}

Data were collected through a survey of English and Portuguese students. This took the form of a selfadministered questionnaire which was made available online in one Portuguese and two English public universities. Before publicising the questionnaire via the institutional pages of the universities, a pilot was carried out in both countries in order to improve and refine the instrument. The survey was open for two months in total, and was made available to students via the institutional web-pages, and/ or by direct emails from administrative staff. For ethical reasons, the students were told that the survey was about energy, and this may have encouraged more knowledgeable students to respond. However, an incentive (prize draw) was also offered for respondents to encourage responses. Students in each institution were given the same information to ensure consistency in approach. The limitations of the sample, entailing two universities in the UK and a single site in Portugal are acknowledged by the authors - and any conclusions drawn should be considered provisional and open to testing in future research. However, the number of respondents in each institution gives us a good sample to work with - and the respondents are broadly speaking representative demographically of those in the whole institution.

The original survey (within the UK) was designed and implemented to address a wider research project (which both the UK universities participated in); however, a sub-set of questions was used to gather 
This is an Accepted Manuscript of an article published by Elsevier in The Journal of Cleaner Production, available at: doi:10.1016/j.jclepro.2016.03.136

comparable data from the Portuguese institution. In this study a particular set of questions has been used to enable comparison. The full questionnaire was designed to gather information about students' perceptions of the environmental practices of their institution in relation to energy use. The instrument included Yes/No questions, measures of attitudes and self-reported behaviours related to energy saving (five-point scales ( $\min 1, \max 5$ ), where 3 is the indifference value), and perception of their own use of energy in terms of level of usage (from $1=$ very low energy user to $5=$ high energy user). Some questions were also posed to gather demographic information such as age, gender and nationality. (See Cotton et al., (2015b) for further information about survey development.) After collection, the data were analysed and interpreted using the statistical software SPSS 21.0 (Statistical Package for Social Sciences). A descriptive analysis was undertaken (frequencies, cross tabulations and central tendency statistics), together with ANOVA and Discriminant tests.

\section{Results}

The sample is composed of 800 (34.9\%) students from the University of Beira Interior (UBI) (Portugal PT), 679 (29.6\%) students from Plymouth University (PU) and 815 (35.5\%) students from Bournemouth University (BU). These last two institutions are located in United Kingdom (UK) and make up $65.1 \%$ of the sample. Gender and age distribution is represented in table 1.

Table 1. Gender and age distribution by institution

\begin{tabular}{|c|c|c|c|c|}
\hline University & \multicolumn{2}{|c|}{ Gender } & \multicolumn{2}{|c|}{ Age } \\
\hline UBI & $\begin{array}{l}\text { Male } \\
\text { Female } \\
\text { Total }\end{array}$ & $\begin{array}{l}310(38,8 \%) \\
490(61,3 \%) \\
800(100 \%)\end{array}$ & $\begin{array}{l}20 \text { or under } \\
21-25 \\
26-35 \\
36-45 \\
46-55 \\
\text { Over } 55 \\
\quad \text { Total } \\
\end{array}$ & $\begin{array}{l}367(45,9 \%) \\
331(41,4 \%) \\
84(10,5 \%) \\
17(2,1 \%) \\
1(0,1 \%) \\
800(100 \%) \\
\end{array}$ \\
\hline $\mathrm{PU}$ & $\begin{array}{l}\text { Male } \\
\text { Female } \\
\text { Missing } \\
\text { Total }\end{array}$ & $\begin{array}{l}198(29,2 \%) \\
473(69,7 \%) \\
8(1,2 \%) \\
679(100 \%)\end{array}$ & $\begin{array}{l}20 \text { or under } \\
21-25 \\
26-35 \\
36-45 \\
46-55 \\
\text { Over 55 } \\
\text { Missing } \\
\quad \text { Total }\end{array}$ & $\begin{array}{c}338(49,8 \%) \\
331(48,7 \%) \\
- \\
- \\
- \\
10(1,5 \%) \\
679(100 \%)\end{array}$ \\
\hline $\mathrm{BU}$ & $\begin{array}{l}\text { Male } \\
\text { Female } \\
\text { Missing } \\
\text { Total }\end{array}$ & $\begin{array}{l}240(29,4 \%) \\
559(68,6 \%) \\
16(2,0 \%) \\
815(100 \%)\end{array}$ & $\begin{array}{l}20 \text { or under } \\
21-25 \\
26-35 \\
36-45 \\
46-55 \\
\text { Over 55 } \\
\text { Missing } \\
\quad \text { Total }\end{array}$ & $\begin{array}{l}209(25,6 \%) \\
361(44,3 \%) \\
147(18,0 \%) \\
54(6,6 \%) \\
30(3,7 \%) \\
4(0,5) \\
10(1,2 \%) \\
815(100 \%)\end{array}$ \\
\hline
\end{tabular}

In all three samples, the number of female participants is higher than the number of males. This was least evident in the Portuguese university, where the percentage of male respondents was highest of the 3 institutions. The two first age groups (20 or under and 21-25) are the largest in all universities. UBI 
This is an Accepted Manuscript of an article published by Elsevier in The Journal of Cleaner Production, available at: doi:10.1016/i.jclepro.2016.03.136

presents the youngest population and BU the oldest.

Regarding the students' perceptions of their campus environmental practices, a set of four general questions was posed. Table 2 shows the results for the three institutions (the highest percentages are shown in bold text).

Table 2. Environmental practices at the university - students' perceptions

\begin{tabular}{l|r|c|c|c}
\hline & Answer & UBI (PT) & PU (UK) & BU (UK) \\
\hline Is there enough information & YES & $21,3 \%$ & $\mathbf{3 2 , 8} \%$ & $22,9 \%$ \\
available on energy use on & NO & $78,8 \%$ & $66,6 \%$ & $76,2 \%$ \\
campus? & No answer & - & $4,0 \%$ & $0,9 \%$ \\
\hline Does the university do enough to & YES & $10,9 \%$ & $\mathbf{3 1 , 7 \%}$ & $15,3 \%$ \\
save energy? & NO & $40,0 \%$ & $23,4 \%$ & $27,2 \%$ \\
& DON'T KNOW & $49,1 \%$ & $44,0 \%$ & $57,3 \%$ \\
& No answer & - & $0,9 \%$ & $0,1 \%$ \\
\hline Are you aware of any initiatives & YES & $3,3 \%$ & $\mathbf{3 2 , 3} \%$ & $20,2 \%$ \\
taken to conserve energy on the & NO & $96,8 \%$ & $67,3 \%$ & $79,4 \%$ \\
university campus? & No answer & - & $0,4 \%$ & $0,4 \%$ \\
\hline Have you seen any of the energy & YES & $6,4 \%$ & $\mathbf{3 8 , 4 \%}$ & $24,8 \%$ \\
certificates displayed on campus & NO & $93,6 \%$ & $60,5 \%$ & $74,4 \%$ \\
buildings? & No answer & - & $1,0 \%$ & $0,9 \%$ \\
\hline
\end{tabular}

As observed, PU students gave the highest percentage of affirmative answers for all elements, followed by $\mathrm{BU}$ and then $\mathrm{UBI}$ (the Portuguese university). At UBI a very low proportion of individuals were aware of initiatives to conserve energy (3.3\%) and of the existence of energy certificates on campus (6.4\%). The difference in this latter value may relate to the different legal context of the two countries: Display Energy Certificates (DECs) are a legal requirement in the UK for buildings over $500 \mathrm{~m}^{2}$ - but this is over and above what is required by EU law, thus such certificates are not commonplace in Portugal. However, the fact that the Portuguese students were less aware of other initiatives to conserve energy suggests that there is a wider issue at play here in terms of the priority placed by institutions on energy saving in the two countries.

In order to find out if there were significant differences between the students of the three universities, regarding their attitudes about energy, a one-way ANOVA was carried out. Table 3 reports the results of analysis on the difference in the means returned by the three subject groups regarding the variables under study. 
This is an Accepted Manuscript of an article published by Elsevier in The Journal of Cleaner Production, available at: doi:10.1016/i.jclepro.2016.03.136

Table 3. Oneway ANOVA for environmental attitudes regarding energy

\begin{tabular}{|c|c|c|c|c|c|c|}
\hline & & $\mathrm{N}$ & Mean & $\begin{array}{l}\text { Standard } \\
\text { Deviation }\end{array}$ & $F$ & Sig. \\
\hline I would do more to save energy if I knew how & $\begin{array}{r}\text { UBI (PT) } \\
\text { PU (UK) } \\
\text { BU (UK) } \\
\text { Total }\end{array}$ & $\begin{array}{c}800 \\
678 \\
814 \\
2292\end{array}$ & $\begin{array}{l}4,07 \\
4,10 \\
4,22 \\
4,13\end{array}$ & $\begin{array}{l}, 953 \\
, 764 \\
, 727 \\
, 826\end{array}$ & 7,897 & 0,000 \\
\hline $\begin{array}{l}\text { The way I personally use energy does not make a } \\
\text { difference to the national energy situation }\end{array}$ & $\begin{array}{r}\text { UBI (PT) } \\
\text { PU (UK) } \\
\text { BU (UK) } \\
\text { Total }\end{array}$ & $\begin{array}{c}800 \\
678 \\
812 \\
2290\end{array}$ & $\begin{array}{l}2,45 \\
2,20 \\
2,28 \\
2,31\end{array}$ & $\begin{array}{c}1,079 \\
, 970 \\
, 982 \\
1,018\end{array}$ & 11,723 & 0,000 \\
\hline $\begin{array}{l}\text { I can influence what the government does about } \\
\text { energy problems }\end{array}$ & $\begin{array}{r}\text { UBI (PT) } \\
\text { PU (UK) } \\
\text { BU (UK) } \\
\text { Total }\end{array}$ & $\begin{array}{c}800 \\
677 \\
811 \\
2288\end{array}$ & $\begin{array}{l}2,86 \\
2,62 \\
2,67 \\
2,72\end{array}$ & $\begin{array}{l}1,014 \\
1,010 \\
1,003 \\
1,014\end{array}$ & 11,546 & 0,000 \\
\hline $\begin{array}{l}\text { I can influence what companies do about energy } \\
\text { problems }\end{array}$ & $\begin{array}{l}\text { UBI (PT) } \\
\text { PU (UK) } \\
\text { BU (UK) } \\
\text { Total }\end{array}$ & $\begin{array}{c}800 \\
675 \\
813 \\
2288\end{array}$ & $\begin{array}{l}2,89 \\
2,57 \\
2,60 \\
2,69\end{array}$ & $\begin{array}{c}, 955 \\
1,030 \\
1,031 \\
1,015\end{array}$ & 23,027 & 0,000 \\
\hline $\begin{array}{l}\text { I trust the government to do something about any } \\
\text { energy problems }\end{array}$ & $\begin{array}{r}\text { UBI (PT) } \\
\text { PU (UK) } \\
\text { BU (UK) } \\
\text { Total }\end{array}$ & $\begin{array}{c}800 \\
676 \\
809 \\
2285\end{array}$ & $\begin{array}{l}2,69 \\
2,34 \\
2,63 \\
2,57\end{array}$ & $\begin{array}{l}1,048 \\
1,007 \\
1,072 \\
1,055\end{array}$ & 22,680 & 0,000 \\
\hline Scientists will find ways to solve energy problems & $\begin{array}{l}\text { UBI (PT) } \\
\text { PU (UK) } \\
\text { BU (UK) } \\
\text { Total }\end{array}$ & $\begin{array}{c}800 \\
678 \\
806 \\
2284\end{array}$ & $\begin{array}{l}3,68 \\
3,58 \\
3,59 \\
3,62\end{array}$ & $\begin{array}{l}, 850 \\
, 866 \\
, 830 \\
, 849\end{array}$ & 3,690 & 0,025 \\
\hline $\begin{array}{l}\text { More wind farms should be developed to generate } \\
\text { electricity, even if they are located in scenic } \\
\text { environments }\end{array}$ & $\begin{array}{r}\text { UBI (PT) } \\
\text { PU (UK) } \\
\text { BU (UK) } \\
\text { Total }\end{array}$ & $\begin{array}{c}800 \\
678 \\
814 \\
2292\end{array}$ & $\begin{array}{l}3,51 \\
3,70 \\
3,64 \\
3,61\end{array}$ & $\begin{array}{l}1,089 \\
1,097 \\
1,084 \\
1,092\end{array}$ & 5,746 & 0,003 \\
\hline $\begin{array}{l}\text { The government should have stronger standards } \\
\text { on fuel efficiency of cars }\end{array}$ & $\begin{array}{r}\text { UBI (PT) } \\
\text { PU (UK) } \\
\text { BU (UK) } \\
\text { Total }\end{array}$ & $\begin{array}{c}800 \\
677 \\
814 \\
2291\end{array}$ & $\begin{array}{l}4,05 \\
4,00 \\
3,97 \\
4,01\end{array}$ & $\begin{array}{l}, 855 \\
, 877 \\
, 856 \\
, 863\end{array}$ & 1,853 & $0,157^{*}$ \\
\hline $\begin{array}{l}\text { Climate change has been established as a } \\
\text { serious problem and immediate action is } \\
\text { necessary }\end{array}$ & $\begin{array}{r}\text { UBI (PT) } \\
\text { PU (UK) } \\
\text { BU (UK) } \\
\text { Total }\end{array}$ & $\begin{array}{c}800 \\
679 \\
811 \\
2290\end{array}$ & $\begin{array}{l}4,39 \\
4,19 \\
4,03 \\
4,21\end{array}$ & $\begin{array}{l}, 754 \\
, 916 \\
, 905 \\
, 871\end{array}$ & 34,909 & 0,000 \\
\hline $\begin{array}{l}\text { Climate change is caused by human activities } \\
\text { related to using energy }\end{array}$ & $\begin{array}{r}\text { UBI (PT) } \\
\mathrm{PU}(\mathrm{PK}) \\
\mathrm{BU} \text { (UK) } \\
\text { Total }\end{array}$ & $\begin{array}{c}800 \\
677 \\
813 \\
2290\end{array}$ & $\begin{array}{l}4,01 \\
3,97 \\
3,92 \\
3,97\end{array}$ & $\begin{array}{l}, 814 \\
, 932 \\
, 928 \\
, 891\end{array}$ & 2,155 & $0,116^{*}$ \\
\hline $\begin{array}{l}\text { There are benefits to people in the country from } \\
\text { climate change }\end{array}$ & $\begin{array}{r}\text { UBI (PT) } \\
\text { PU (UK) } \\
\text { BU (UK) } \\
\text { Total }\end{array}$ & $\begin{array}{c}800 \\
676 \\
811 \\
2287\end{array}$ & $\begin{array}{l}2,46 \\
2,44 \\
2,66 \\
2,53\end{array}$ & $\begin{array}{c}1,122 \\
1,016 \\
, 997 \\
1,052\end{array}$ & 11,012 & 0,000 \\
\hline
\end{tabular}

Note: Five point scale 1- Strongly disagree, 2- Disagree, 3- Neither agree or disagree, 4- Agree, 5- Strongly agree

$\left.{ }^{\star}\right)$ non-significant for $\mathrm{p}<0,05$

In general, the Portuguese students seemed to have more positive attitudes towards energy conservation than the English students. However, the BU students were most likely to claim that they would do more to save energy if they knew how, and PU students most likely to take responsibility for the impact of their own use of energy, and were more enthusiastic about wind farms than the other groups. All variables except for two (when considered individually), show significant differences between the groups (at $p>0,05$ ). As there were differences between the students from the UK and PT, regarding attitudes related to energy conservation for the majority of the variables, it is possible to reject $\mathrm{H}_{1}$. 
This is an Accepted Manuscript of an article published by Elsevier in The Journal of Cleaner Production, available at: doi:10.1016/j.jclepro.2016.03.136

Similar analysis was carried out for reported environmental behaviours regarding energy (table 4).

Table 4. Oneway ANOVA for reported energy-saving behaviours

\begin{tabular}{|c|c|c|c|c|c|c|}
\hline & & $\mathrm{N}$ & Mean & $\begin{array}{l}\text { Standard } \\
\text { Deviation }\end{array}$ & $\mathrm{F}$ & Sig. \\
\hline Turn off lights when they are not in use & $\begin{array}{r}\text { UBI (PT) } \\
\text { PU (UK) } \\
\text { BU (UK) } \\
\text { Total }\end{array}$ & $\begin{array}{r}800 \\
679 \\
813 \\
2292\end{array}$ & $\begin{array}{l}3,51 \\
3,61 \\
3,64 \\
3,59\end{array}$ & $\begin{array}{r}, 566 \\
, 556 \\
, 529 \\
, 552\end{array}$ & 11,828 & 0,000 \\
\hline Turn down the heat & $\begin{array}{c}\text { UBI (PT) } \\
\text { PU (UK) } \\
\text { BU (UK) } \\
\text { Total }\end{array}$ & $\begin{array}{r}800 \\
678 \\
810 \\
2288\end{array}$ & $\begin{array}{l}3,01 \\
3,12 \\
3,15 \\
3,09\end{array}$ & $\begin{array}{l}, 760 \\
, 772 \\
, 760 \\
, 766\end{array}$ & 7,372 & 0,001 \\
\hline Try to save water & $\begin{array}{c}\text { UBI (PT) } \\
\text { PU (UK) } \\
\text { BU (UK) } \\
\text { Total }\end{array}$ & $\begin{array}{r}800 \\
676 \\
809 \\
2285\end{array}$ & $\begin{array}{l}3,14 \\
3,13 \\
3,09 \\
3,12\end{array}$ & $\begin{array}{l}, 667 \\
, 750 \\
, 777 \\
, 732\end{array}$ & 1,309 & $0,270^{*}$ \\
\hline Walk or cycle short distances instead of going by car & $\begin{array}{c}\text { UBI (PT) } \\
\text { PU (UK) } \\
\text { BU (UK) } \\
\text { Total }\end{array}$ & $\begin{array}{r}800 \\
677 \\
812 \\
2289\end{array}$ & $\begin{array}{l}2,95 \\
3,31 \\
3,15 \\
3,13\end{array}$ & $\begin{array}{l}, 914 \\
, 775 \\
, 849 \\
, 863\end{array}$ & 33,962 & 0,000 \\
\hline $\begin{array}{l}\text { Buy things that are likely to involve less energy or } \\
\text { resource use }\end{array}$ & $\begin{array}{r}\text { UBI (PT) } \\
\text { PU (UK) } \\
\text { BU (UK) } \\
\text { Total }\end{array}$ & $\begin{array}{r}800 \\
676 \\
811 \\
2287\end{array}$ & $\begin{array}{l}2,41 \\
2,55 \\
2,51 \\
2,49\end{array}$ & $\begin{array}{l}, 765 \\
, 818 \\
, 839 \\
, 809\end{array}$ & 5,518 & 0,004 \\
\hline Pay a bit more for environmentally friendly products & $\begin{array}{r}\text { UBI (PT) } \\
\text { PU (UK) } \\
\text { BU (UK) } \\
\text { Total }\end{array}$ & $\begin{array}{r}800 \\
679 \\
811 \\
2290\end{array}$ & $\begin{array}{l}2,32 \\
2,49 \\
2,41 \\
2,40\end{array}$ & $\begin{array}{l}, 743 \\
, 845 \\
, 844 \\
, 813\end{array}$ & 8,589 & 0,000 \\
\hline Avoid charging mobile phones overnight & $\begin{array}{r}\text { UBI (PT) } \\
\text { PU (UK) } \\
\text { BU (UK) } \\
\text { Total }\end{array}$ & $\begin{array}{r}800 \\
674 \\
809 \\
2283\end{array}$ & $\begin{array}{l}2,20 \\
1,94 \\
1,97 \\
2,04\end{array}$ & $\begin{array}{r}, 921 \\
1,003 \\
1,025 \\
, 989\end{array}$ & 15,357 & 0,000 \\
\hline $\begin{array}{l}\text { Turn off the stand-by button of the TV set or switch } \\
\text { appliances off at the plug }\end{array}$ & $\begin{array}{c}\text { UBI (PT) } \\
\text { PU (UK) } \\
\text { BU (UK) } \\
\text { Total }\end{array}$ & $\begin{array}{r}800 \\
679 \\
808 \\
2287\end{array}$ & $\begin{array}{l}2,58 \\
3,00 \\
2,91 \\
2,82\end{array}$ & $\begin{array}{r}, 953 \\
1,023 \\
1,007 \\
1,009\end{array}$ & 38,036 & 0,000 \\
\hline Use rechargeable batteries & $\begin{array}{c}\text { UBI (PT) } \\
\text { PU (UK) } \\
\text { BU (UK) } \\
\text { Total }\end{array}$ & $\begin{array}{r}800 \\
676 \\
807 \\
2283 \\
\end{array}$ & $\begin{array}{l}2,39 \\
2,65 \\
2,51 \\
2,51 \\
\end{array}$ & $\begin{array}{l}, 935 \\
, 968 \\
, 972 \\
, 963 \\
\end{array}$ & 13,699 & 0,000 \\
\hline
\end{tabular}

Note: Four points scale 1- Never, 2- Infrequently, 3- Frequently, 4- Always

Regarding reports of environmentally friendly behaviours, PU exhibits the highest scores for almost all aspects (walk or cycle, buy things with less energy/resources involved, pay more for green products, turn off the stand-by button, and use rechargeable batteries). In this set of statements, BU is highest on "Turning off lights when they are not in use" as well as "Turn down the heat", and UBI (PT) is superior in "Avoid charging mobile phones overnight". The latter behaviour is one that is infrequently reported across all universities and is an issue which is generally poorly understood by students (Cotton et al., 2015b). By observing the results of $\mathrm{F}$ statistics, all the variables are significant for differentiating between the groups $(p<0,05)$ except the variable "Try to save water" $(p>0,05)$, which nonetheless allows us to reject $\mathrm{H}_{2}$. In this case the individuals from the two countries seems to have similar reported behaviours regarding water saving. Note that this mean value points to a frequently reported behaviour.

The final comparison concerns the individuals' own perception of their level of energy usage. Table 5 details the results. 
This is an Accepted Manuscript of an article published by Elsevier in The Journal of Cleaner Production, available at: doi:10.1016/i.jclepro.2016.03.136

Table 5. Oneway ANOVA for personal use of energy

\begin{tabular}{lcccccc}
\hline & & $N$ & Mean & $\begin{array}{c}\text { Standard } \\
\text { Deviation }\end{array}$ & F & Sig. \\
\hline & UBI (PT) & 800 & 3,02 &, 603 & & \\
When it comes to energy use, how would you & PU (UK) & 672 & 2,91 &, 651 & 6,735 & 0,001 \\
describe yourself? & BU (UK) & 807 & 3,01 &, 658 & & \\
& Total & 2279 & 2,98 &, 639 & & \\
\end{tabular}

Note: Five points scale: 1= Very low energy user; 2= Low energy user; 3= Medium energy user; 4= Moderately high energy user; $5=$ High energy user

This analysis indicates significant differences between the three groups of students regarding the perceived level of energy usage, with the Portuguese university having the highest level, and PU the lowest. Thus it is possible to reject $\mathrm{H}_{3}$ (There are no significant differences between students of the universities in the United Kingdom and Portugal regarding their perception of their own energy usage).

To explore the existence of a relationship between the students' perceptions and reported behaviours across all respondents from the three samples, the set of items related to energy behaviour were compared with the question "When it comes to energy use, how would you describe yourself?" In general most individuals considered themselves to be medium users, yet reports of specific behaviours varied as follows:

- "Turn off lights when they are not in use": $66,1 \%$ of the respondents stated that they did this frequently or always $(r=-0,240, p=0,000)$;

- "Turn down the heat": $54,7 \%$ of the respondents stated that they did this frequently or always ( $r=$ $-0,240, p=0,000$ );

- "Try to save water": $54,7 \%$ of the respondents stated that they did this frequently or always ( $r=-$ $0,260, p=0,000)$

- "Walk or cycle short distances instead of going by car": $55,7 \%$ of the respondents stated that they did this frequently or always $(r=-0,246, p=0,000)$;

- "Buy things that are likely to involve less energy or resource use": In this case, the majority selected the option 'infrequently' $(31,9 \%)(r=-0,182, p=0,000)$;

- "Pay a bit more for environmentally friendly products": In this case, the majority also selected the option 'infrequently' $(33,2 \%)(r=-0,174, p=0,000)$;

- "Avoid charging mobile phones overnight": $48,3 \%$ of the respondents stated that they did this 'never' or 'infrequently' $(r=-0,177, p=0,000)$;

- "Turn off the stand-by button of the TV set or switch appliances off at the plug": $41,1 \%$ of the respondents stated that they did this frequently or always $(r=-0,221, p=0,000)$;

- "Use rechargeable batteries": $46,2 \%$ of the respondents stated that they did this 'never' or 'infrequently' $(r=-0,108, p=0,000)$.

These results point to a relationship between the perception of energy usage and self-reported energy saving behaviours. It is a negative correlation: thus, the self-confessed higher energy users are generally 
This is an Accepted Manuscript of an article published by Elsevier in The Journal of Cleaner Production, available at: doi:10.1016/i.jclepro.2016.03.136

less likely to report undertaking all forms of energy-conservation behaviour. Note, however, that in some cases (items related with buying more environmentally friendly products, avoiding charging mobile phones overnight and using rechargeable batteries) even the majority of self-identified 'medium users' do not report undertaking these behaviours most of the time. Despite the significance of the correlations, the Spearman statistic presents low values, pointing to a weak association. This is confirmed by the use of a One Way Anova to explore any differences between groups of students classified by energy usage. For all reported energy saving behaviours, no significant differences were found between the categories of users (Very low, Low, Medium, Moderately high and High) $(p<0,05)$.

Using the demographic data, when gender is cross tabulated with this question, the following results are obtained (table 6).

Table 6. Use of energy versus gender (number of individuals)

\begin{tabular}{llllll}
\hline $\begin{array}{l}\text { When it comes to energy use, } \\
\text { how would you describe }\end{array}$ & & & Female & Total & $\begin{array}{l}\text { Sig. } \\
\text { tailed) }\end{array}$ \\
$\begin{array}{l}\text { yourself? } \\
\text { Very low energy user }\end{array}$ & 13 & 14 & 27 & \\
Low energy user & 119 & 243 & 362 & \\
Medium energy user & 482 & 1043 & 1525 & 0,295 & \\
Moderately high energy user & 117 & 192 & 309 & \\
High energy user & 15 & 19 & 34 & \\
Total & 746 & 1511 & 2257 & \\
\hline
\end{tabular}

Note: t-test for equality of means with $\mathrm{p}<0.05$

The hypothesis which states that there are no significant differences between males and females regarding their own perception of the usage of energy $\left(\mathrm{H}_{3.1}\right)$ is therefore accepted.

\section{Discussion}

Universities have a key role to play in transforming societies (Barth and Rieckmann, 2012), and across the world, a number of institutions are increasingly attempting to contribute to sustainability through teaching, research and campus developments. However, variations in national and institutional context may impact on the effectiveness of these efforts. As Stephens et al. (2008) note: "The potential for higher education to be a change agent accelerating a transition toward sustainability is dependent on a variety of factors including the current position, structure, and arrangement of higher education within its society as well as the locationspecific sustainability challenges and opportunities facing a given community or region." (p. 322). Similarly, research across seven countries by Ferrer-Balas et al. (2008) illustrates differences in the effectiveness of institutional transformation efforts towards sustainability in different contexts. The Spanish university in their research, for example, was one of the first to consider institution-wide sustainability measures in the country 
This is an Accepted Manuscript of an article published by Elsevier in The Journal of Cleaner Production, available at: doi:10.1016/i.jclepro.2016.03.136

and thus encountered barriers which simply did not apply in some of the other contexts. This may help explain some of the differences which were observed between the two UK universities and the Portuguese institution in this study. Research by Paço et al. (2013) showed that Portuguese students had relatively low engagement with conservation activities compared to students in the other countries involved; thus the overall results from this study echo the findings of earlier research in the specific context of energy saving.

The findings on campus energy initiatives illustrate a difference between the two UK universities (with PU having the highest level of awareness of energy saving on campus across all areas). These differences might be somewhat explained by the universities' respective positions in the Green League and the particular foci adopted at each institution, where PU emphasises EfS more strongly and BU emphasises global citizenship. Wals notes the potential for rankings to impact on EfS in HE, at least for those institutions outside the traditional research elite where there is generally more interest in curriculum development and in sustainability (Wals, 2014). The tactic taken by such league tables could be compared to the use of so-called 'smart regulation' approaches used in energy industries to inspire cleaner production (Dirckinck-Holmfeld, in press). Rather than a 'command and control' approach, such methods encourage change by using market-based solutions, and aligning with other policy changes. In the case of the Green League, there is some evidence that students select universities on the basis of their environmental credentials (Drayson et al., 2013) and, with regard to energy saving, efforts towards success in the Green League also align with carbon reduction targets for the institution. A limitation of this approach - as evidenced in our study - is that such efforts may be seen as additional rather than core university business, and therefore commitment to them highly variable and potentially vulnerable to cuts when resources are scarce (Dirckinck-Holmfeld, in press).

There was also a marked difference between the UK institutions and the Portuguese university - with the latter having a much lower awareness of energy initiatives on campus than either of those in the UK, as well as lower visibility of energy certificates. Although this may be related to the legal requirement in terms of whether there is a need for energy certificates to be displayed, it may also indicate the impact of activities such as the Green League on promoting campus greening in the UK. There are also, however, other differences between the universities within this sample which may help explain differences in response to this question. These include the type of buildings on campus. Research indicates that there is a significant relationship between building age and energy consumption in the HE sector (Ward et al., 2008). The older, historic buildings at UBI may therefore act as a barrier to more energy-saving behaviour on the part of the university, and this may partially explain the lack of awareness of initiatives. However, at UBI the lack of information about sustainability policies available on the website was also noted; thus the academic community is largely unaware of institutional sustainability practices. Issues around communicating sustainability issues within the university environment have been raised in previous research by Djordjevic and Cotton (2011). They conclude that there are many barriers to effective communication in this context - not least the complexity of the issue and the perceptual filters of the receivers. Even where communicated widely, the students and staff who are targeted by a campus energy-saving initiative may have very different views about desirable outcomes to those delivering the message, underlining the importance of effective dialogue.

When examining the attitudes towards energy issues, a very different pattern is observed with the Portuguese students having significantly more positive attitudes on 6 of the 9 items where a significant difference was 
This is an Accepted Manuscript of an article published by Elsevier in The Journal of Cleaner Production, available at: doi:10.1016/i.jclepro.2016.03.136

found. Given that female students generally have more positive environmental attitudes (Zelezny et al., 2000), and the proportion of female students is lowest in the Portuguese university, this is particularly surprising. The difference in responses is especially noticeable on the questions which involve collective agency (ability to influence the actions of government and companies), as well as those on the seriousness of climate change. One possible explanation for this is that these questions relate to some degree to environmental activism, an area in which males are known to be more active than females. This finding seems to run counter to the prior literature, however, which reports Portuguese students as having relatively low environmental concern (Paço et al., 2013); thus it is possible that UBI students are more environmentally concerned than their peers.

In terms of reported energy-saving behaviour, PU students reported the highest levels of positive behaviours (higher on 5 of the 8 items where a significant difference was found). BU takes the lead on two areas, and in most cases students from the two UK universities report levels of energy-saving behaviours well above those of the Portuguese institution. This fits with the gender pattern of some previous research: the impact of gender on pro-environmental behaviour is reported to be even stronger than on attitudes, according to Zelezny et al. (2000), and the Portuguese sample is the one with fewest females. However, gender differences are not sufficient to explain fully the variation between the universities, since the two UK institutions have very similar gender balance in respondents, and yet differ on this measure. In addition, the different patterns when comparing attitudes with reported behaviours echoes the claim made earlier that there is not a necessary correlation between these elements - thus, although the Portuguese students seem to be more environmentally concerned, they are actually less likely to report energy saving behaviours.

It perhaps should be noted that the difference between the two sets of question may also be related to the sphere of influence to which they refer. A paper by Testa et al. (2015) describes two fundamental categories of energy-saving behaviour: 'Curtailment behaviour' (turning off lights, using less paper) and 'investment behaviour' (adopting energy-efficient technologies; buying goods which involve less energy). Both of these types of behaviour concern individual action (as did many of the behaviours used in our survey), and in this sphere, the UK students appear to be ahead. However, there is also a third kind of activity which could (indirectly) result in energy-saving on a far larger scale, and that is 'democratic or collaborative behaviour', involving utilising the agency of individuals or groups to influence change through the government or businesses. Although not directly represented in our behavioural items, this was indirectly measured through the attitudinal variables (such as 'I can influence what the government does about energy problems'; 'I can influence what companies do about energy problems') - and on these items the difference between the UK and Portuguese students was in the opposite direction. Thus it may be the case that UK students are more focused on individual agency, and Portuguese students more focused on collective agency.

This interpretation is supported by some previous research on environmental activism and community-based environmental movements in Spain, Greece and Portugal (Kousis, 1999) which describes activities in these countries as characterised by "intense unconventional political participation" (p. 179). Evidence of environmental participation is less strong in terms of joining formal NGOs, but stronger in terms of small-scale grass-roots movements. Another study, however, analysing civic participation in Portugal (at a general level and with regard to the environment), observed strong evidence of an assumed passivity in relation to the exercise of citizenship: levels of militancy were very low, as were the subscription to public petitions and participation in public meetings of environmental associations (Almeida, 2001). However, this study seems to 
This is an Accepted Manuscript of an article published by Elsevier in The Journal of Cleaner Production, available at: doi:10.1016/j.jclepro.2016.03.136

overlook the potential for different forms of 'unofficial' environmental activism as recounted in the Kousis' study: "The present work attempts to point out the significance of grass-roots mobilisations, not only in terms of their stronger than expected presence, but in terms of their commitment and level of consciousness as well." (Kousis, 1999, p. 192). Clearly this area would merit further research to explore explicitly the differences in wider environmental movements and activism and their potential impacts on attitudes and reported or actual behaviours.

There are obviously limits to the claims that can be made on the basis of this sample. Whilst the findings give some interesting indicators of where, and why, differences might occur across different student populations, the research is limited by the number of institutions involved. Nonetheless, as an exploratory study, the results suggest that this is an area that needs further investigation. Even if the observed differences do turn out to be related to institutional rather than national factors (in terms of the extent to which each institution engages with sustainability issues), this in itself is worthy of further investigation. It would be of interest to explore whether the initiatives at PU, for example, might lend themselves to the development of a particular kind of student who is more likely to conserve energy whilst at university and in future. Likewise, further research might explore the extent to which more energy-conscious students are attracted to an institution that markets its green credentials. An extension of the study across Europe or internationally would be of significant interest and enable conclusions to be drawn about the influence of institutional approaches and the over-arching influence of cultural context. To strengthen future research, we would recommend the inclusion of actual measures of energy use wherever possible, to supplement, challenge or confirm the student self-reports provided.

\section{Conclusions}

This study set out to compare English and Portuguese students' perceptions of their campus' environmental practices and to explore their attitudes and reported energy-saving behaviours - an area which has not previously been explored in the literature. The research used an online survey to investigate whether there were any significant differences between students' attitudes and reported energy conservation behaviours between different institutions and countries. It is one of the first studies to attempt such a comparison, and the results indicate that there are differences between the students' responses at the selected universities which appear to reflect the national context and diverse institutional priorities. Key differences include the variation between students' perceptions of individual agency and their university's environmental practices (stronger in the UK) and students' sense of collective agency and trust in the government and business (stronger in Portugal). The pattern of responses suggests that students in the different national and institutional contexts studied have differing attitudes and report undertaking different types of energy saving behaviours, as well as having differing perceptions of their own energy usage. Thus three of the null hypotheses initially formulated are rejected. However in relation to gender differences, the hypothesis must be accepted: in fact there are no significant differences between male and female students regarding their perception of their own energy usage.

There are clearly some limitations to the methodology in terms of the numbers of institutions sampled. However, a large number of students were involved in completing the survey, and the research contributes to the literature in providing plausible explanations for both institutional and national variations in responses. The 
This is an Accepted Manuscript of an article published by Elsevier in The Journal of Cleaner Production, available at: doi:10.1016/j.jclepro.2016.03.136

scientific value of the study is in the contribution it makes to a research gap: there is much written about education for sustainable development in universities, and about environmental management, but a paucity of studies that evaluate the influence of such efforts on students. These results (and the online survey developed) can be used as a foundation to extend the comparison to other institutions and other countries and also to expand the research to encompass actual energy use in relation to perceived energy use. In addition, qualitative research exploring in more depth both students' perspectives and the various policy discourses on energy conservation, would be beneficial to enhance understanding of the observed differences found in this study. This research provides tentative evidence that the policy context, including developments such as the UK Green League and legal requirements regarding carbon management and energy certificates, does impact on students' perceptions of energy saving at their institution. If replicated by other studies, these findings imply that a strengthened focus both on legislative efforts and 'market based solutions' such as league tables could assist in energy conservation efforts in other countries. 
This is an Accepted Manuscript of an article published by Elsevier in The Journal of Cleaner Production, available at: doi:10.1016/i.jclepro.2016.03.136

\section{References}

Almeida, J.F., 2001. II Inquérito Nacional: Os Portugueses e o Ambiente. Resume. Research Project OBSERVA, ISCTE, Lisboa.

Attari, S.Z., DeKay, M.L., Davidson, C.I., Bruine de Bruin, W., 2010. Public perceptions of energy consumption and savings. PNAS 107(37), pp. 6.

Balderjahn, I., 1988. Personality variables and environmental attitudes as predictors of ecologically responsible consumption patterns. J. Bus. Res. 17, 51-56.

Bamberg, S., Möser, G., 2007. Twenty years after Hines, Hungerford, and Tomera: a new meta-analysis of psycho-social determinants of pro-environmental behaviour. J. Environ. Psychol. 27(1), 14-25.

Barth, M., Rieckmann, M., 2012. Academic staff development as a catalyst for curriculum change towards education for sustainable development: an output perspective. J. Clean. Prod. 26, 28-36.

Barr, S. 2007. Factors influencing environmental attitudes and behaviors a UK case study of household waste management. Environ.Behav 39(4), 435-473.

Barr S, Barr S.W, Shaw G., Coles T., Coles T.E. 2011a. Times for (Un)sustainability? Challenges and opportunities for developing behaviour change policy. Global Environ. Chang. 21, 1234-1244

Barr, S., Gilg, A., Shaw, G. 2011b. 'Helping People Make Better Choices': Exploring the behaviour change agenda for environmental sustainability. Appl. Geogr. 31(2), 712-720.

Brounen, D., Kok, N., Quigley, J.M., 2012. Residential energy use and conservation: economics and demographics. Eur. Econ. Rev. 56(5), 931-945.

BU, 2018. Bournemouth University Strategic Plan. Retrieved from: http://strategicplan.bournemouth.ac.uk/ (accessed $1^{\text {st }}$ March 2015).

Cleveland, M., Kalamas, M., Laroche, M., 2005. Shades of green: linking environmental locus of control and pro-environmental behaviors. J. Consum. Mark. 22(4), 198-212.

Cotton, D.R.E., Winter, J., Bailey, I., 2013. Researching the hidden curriculum: intentional and unintended messages. J. Geog. Higher Educ. 37(2), 192-203.

Cotton, D.R.E., Miller, W., Winter, J., Bailey, I., Sterling, S. 2015a. Developing students' energy literacy in higher education. Int. J. Sust. Higher Educ. 16 (4), 456-473.

Cotton, D.R.E, Miller, W., Winter, J. Bailey, I., Sterling, S. 2015b. Knowledge, agency and collective action as barriers to energy-saving behaviour. Local Environment. Early edition available online at: http://www.tandfonline.com/doi/abs/10.1080/13549839.2015.1038986?journalCode=cloe20

Creighton, S.H., 1999. Greening the Ivory Tower. Improving the Environmental Track Record of Universities, Colleges, and Other Institutions. MIT Press, Cambridge.

DeWaters, J., Powers, S., 2013. Establishing Measurement Criteria for an Energy Literacy Questionnaire. J. Environ. Educ. 44(1), 38-55.

Dirckinck-Holmfeld, K. (in press). The options of local authorities for addressing climate change and energy efficiency through environmental regulation of companies. J. Clean. Prod. Retrieved from http://dx.doi.org/10.1016/i.jclepro.2014.12.067 (accessed 10 th March 2015).

Djordjevic, A., Cotton, D.R.E. 2011. Communicating the Sustainability Message in Higher Education Institutions. Int. J. Sustain. Higher Ed. 12 (4), 381-394. 
This is an Accepted Manuscript of an article published by Elsevier in The Journal of Cleaner Production, available at: doi:10.1016/i.jclepro.2016.03.136

Drayson, R., Bone, E., Agombar, J.,Kemp, S. 2013. Student attitudes towards and skills for sustainable development. NUS/HEA, York. Retrieved from: https://www.heacademy.ac.uk/resource/2013-studentattitudes-towards-and-skills-sustainable-development (accessed 10 th October 2015).

EAUC, 2015. Learning in Future Environments - LIFE. Retrieved from:

http://www.eauc.org.uk/green_gown_awards (accessed $10^{\text {th }}$ December 2015).

Ferrer-Balas, D., Adachi, J., Banas, S., Davidson, C.I., Hoshikoshi, A., Mishra, A., Motodoa, Y. Onga, M. and Ostwald, M. 2008. An international comparative analysis of sustainability transformation across seven universities. Int. J. Sustain. Higher Ed. 9 (3), 295-316

Gardner, G.T., Stern, P.C., 2008. The short list: the most effective actions US households can take to curb climate change. Environ. Sci. Policy Sustain. Dev. 50(5), 12-25.

Geller, H., Harrington, P., Rosenfeld, A.H., Tanishima, S., Unander, F., 2006. Polices for increasing energy efficiency: thirty years of experience in OECD countries. Energ. Policy 34(5), 556-573.

HEFCE, 2005. Sustainable Development in Higher Education: Strategic Statement and Action Plan. Higher Education Funding Council for England, Bristol.

HEFCE, 2009. Sustainable development in higher education: 2008 update to strategic statement and action plan. Higher Education Funding Council for England, Bristol.

HEFCE, 2010. Carbon reduction target and strategy for Higher Education in England. Higher Education Funding Council for England, Bristol.

Hines, J., Hungerford, H., Tomera, H., 1987. Analysis and synthesis of research on responsible environmental behavior: a meta-analysis. J. Environ. Educ. 18(2), 1-8.

Hume, M., 2010. Compassion without action: examining the young consumers' consumption and attitude to sustainable consumption. J. World Bus. 45(4), 385-394.

IPCC, 2014. Summary for Policymakers, in: Edenhofer, O. et al. (Eds), Climate Change 2014: Mitigation of Climate Change. Contribution of Working Group III to the Fifth Assessment Report of the Intergovernmental Panel on Climate Change. Cambridge University Press, Cambridge, United Kingdom and New York, NY, USA.

Jones, P., Selby, D., Sterling, S., 2010. Sustainability education: Perspectives and practice across higher education. Earthscan, London.

Kastener, I., Matthies, E., 2014. Implementing web-based interventions to promote energy efficient behavior at organizations - a multi-level challenge. J. Clean. Prod. 62, 89-97.

Kousis, M. 1999. Sustaining Local Environmental Mobilisations: Groups, Actions and Claims in Southern Europe. Environ. Polit. 8:1, 172-198.

Laroche, M., Bergeron, J., Barbaro-Forleo, G., 2001. Targeting consumers who are willing to pay more for environmentally friendly products. J. Consum. Mark. 18(6), 503-520.

Leal Filho, Walter (ed.) 2000. Sustainability and University Life. Peter Lang Scientific Publishers, Frankfurt.

Leal Filho, W.,Shiel, C. ,Paço, A. 2015. Integrative Approaches to Environmental Sustainability at Universities: an overview of challenges and priorities. J. Integr. Environ. Sci. 12(1), 1-14.

Lukman, R., Lozano, R., Vamberger, T., Krajnc, M., 2013. Addressing the attitudinal gap towards improving the environment: a case study from a primary school in Slovenia. J. Clean. Prod. 48, 93-100. 
Liu, S.Y., Yeh, S.C., Liang, S.W., Fang, H.T., Tsai, H.M., 2015. A national investigation of teachers' environmental literacy as a reference for promoting environmental education in Taiwan. J. Environ. Educ. 46(2), 114-132.

Lorenzoni, I., Nicholson-Cole, S., Whitmarsh, L., 2007. Barriers perceived to engaging with climate change among the UK public and their policy implications. Global Environ. Chang. 17 (3/4), 445-459.

Mohai, P., 1992. Men, women, and the environment: An examination of the gender gap in environmental concern and activism. Soc. Nat. Resour. 5(1), 1-19.

O'Shaughnessy, S., Kennedy, E.H., 2010. Relational activism: reimagining women's environmental work as cultural change. Can. J. Sociol. 35(4), 551-572.

Orr, D.W., 1994. Earth in Mind: on Education, Environment, and the Human Prospect. Island Press, Washington.

Paço, A., Alves, H., Shiel, C., Leal Filho, W., 2013. Conserving behaviour: a replication of the ENVIROCON scale in four countries. APCBEE Procedia 5, 44-49.

People \& Planet Organisation, 2015. UK People and Planet Green League. Retrieved from: http://peopleandplanet.org/greenleague (accessed 15th March 2015).

Pickett G.M., Kangun N., Grove S.J., 1995. An examination of the conservative consumer: implications for public formation policy in promoting conservation behaviour, in: Polonsky M.J., Mintu-Wimsatt A.T. (Eds), Environmental Marketing: Strategies, Practice, Theory and Research, The Haworth Press, New York, pp. 77-99.

Shephard, K., 2008. Higher education for sustainability: seeking affective learning outcomes. Int. J. Sustain. Higher Educ. 9(1), 87-98.

Shephard, K., Mann, S., Smith, M., Deaker, L., 2009. Benchmarking the environmental values and attitudes of students in New Zealand's post-compulsory education. Environ. Educ. Res. 15(5), 571-587.

Shiel, C., Paço, A., 2012. Do formal policies for sustainable development make a difference? A comparison of students from two different universities, one in the UK and one in Portugal, in: Leal Filho, W. (Ed.), Sustainable Development at Universities: New Horizons. Peter Lang Scientific, Germany.

Shiel, C., Williams, A., 2015. Working together, driven apart: reflecting on a joint endeavour to address sustainable development within a university, in: Leal Filho W et al. (Eds.), Integrative Approaches to Sustainable Development at University Level, World Sustainability Series. Springer International Publishing, Switzerland, pp. 425-447.

Sterling, S., Maxey, L., Luna, H., 2013. The Sustainable University: Progress and Prospects. Earthscan/Routledge, London and New York.

Stephens, J.C., Hernandez, M.E., Román, M., Graham, A.C. and Scholz, R.W. 2008. Higher education as a change agent for sustainability in different cultures and contexts, Int. J. Sustain. Higher Ed. 9 (3), 17-338.

Testa, F., Cosic, A., Iraldo, F. 2015 (in press). Determining factors of curtailment and purchasing energy related behaviours. J. Clean. Prod. 1-10,

Thomashow, M., 2014. The Nine Elements of a Sustainable Campus. The MIT Press London.

Tikka, P., Kuitunen, M., Tynys, S., 2000. Effects of educational background on students' attitudes, activity levels, and knowledge concerning the environment. J. Environ. Educ. 31(3), 12-19.

UNESCO, 2005. UN Decade of Education for Sustainable Development 2005-2014. UNESCO - 
This is an Accepted Manuscript of an article published by Elsevier in The Journal of Cleaner Production, available at: doi:10.1016/j.jclepro.2016.03.136

Education for Sustainable Development (ED/PEQ/ESD). Retrieved from http://unesdoc.unesco.org/images/0014/001416/141629e.pdf (accessed 16 ${ }^{\text {th }}$ March 2015)

Wals, A.E.J., 2014. Sustainability in higher education in the context of the UN DESD: a review of learning and institutionalization processes. J. Clean. Prod. 62, 8-15.

Ward, I., Ogbonna, A., Altan, H., 2008. Sector review of UK higher education energy consumption. Energ. Policy. 36, 2939- 2949.

Winter, J., Cotton, D.R.E., 2012. Making the hidden curriculum visible: sustainability literacy in higher education. Environ. Educ. Res. 18(6), 783-796.

Zelezny, L.C., Chua, P., Aldrich, C., 2000. Elaborating on gender differences in environmentalism. J. Soc. Issues 56(3), 443-357 